\title{
Evaluation of Advanced Chemical Oxidation Process for the Pretreatment of Mixed Agro-Food Industrial Wastewater in Nablus, Palestine
}

\section{Saja Younes, Rashed Al-Sa`ed ${ }^{*}$ ID}

Institute of Environmental and Water Studies (IEWS), Birzeit University (BZU), Birzeit, Palestine.

\begin{abstract}
This study investigated the reduction of organic loads from mixed agro-food industrial wastewaters (dairy and slaughterhouse) of Nablus city using advanced oxidation process (AOP), a high- rate chemical oxidation reaction. Bench scale Jar tests using an advanced oxidation process (AOP) were performed as a pretreatment stage. Direct applications of classical Fenton's process on mixed raw agro- food wastewater samples (COD: 15400-18200 mg/l) revealed unsatisfactory results. The performance of Fenton process was evaluated using three mixed samples with different pre-treatment trials: (A) coagulant $\left(\mathrm{FeCl}_{3} \cdot 6 \mathrm{H}_{2} \mathrm{O}\right)$ addition, (B) settling (2h) allowed and use of flocculent (lime $\left.\mathrm{Ca}(\mathrm{OH})_{2}\right)$ in sample $(\mathrm{C})$. Compared with other partial treatments, sample $(\mathrm{C})$, Fenton`s process lime preceded, was the most effective in the removal of organic $(89 \%$ COD; $80 \%$ TKN) and inorganic loads (91\% TSS; 62\% TS) under $\mathrm{H}_{2} \mathrm{O}_{2} / \mathrm{COD}(\mathrm{w} / \mathrm{w}$ ratio 2:1), $\mathrm{H}_{2} \mathrm{O}_{2} / \mathrm{Fe}^{+2}(\mathrm{w} / \mathrm{w}$ ratio 10:1) and acidic conditions $(\mathrm{pH}=3)$. Obtained results comply with Nablus municipal by-law (COD below $2000 \mathrm{mg} / \mathrm{l}$ ), which help decision makers within the agro-food industries install pollution reduction systems. Investment in Fenton-based peroxidation process, allow agro-food industries obtain connection permits to sewage networks.
\end{abstract}

Keywords: Advanced oxidation processes; Fenton reaction; agro-industrial wastewater; municipal by-laws; sewer connection permit.

*Corresponding author: E-mail address: rsaed@birzeit.edu 


\section{Introduction}

Agro-food industries wastewater had been categorized as one of the main pollution and harmful source for the environment, public sewerage, and municipal wastewater treatment plants, well as un-accepted wastewater characteristics [1].

The dairy and slaughterhouse are both kind of agro-food industrial wastewater, which have high biological oxygen demand (BOD) [1], this high BOD level due to whey and blood [2], The wastewater of dairy factories and there are many and varied and have a harmful effect on the environment. The most important of these wastes is the water produced by the manufacturing process because of its content of proteins, fats, and salts [3]. In addition, the remnants of the slaughterhouse due to the blood and the proudest wastewater from slaughtered animal [4]. Therefore, focus on disposal of these wastes in a proper manner so as not to reach the sewage or other of environmental problems.

In Palestine current water and environmental laws and water regulations, place national limits on industrial discharges and treated effluent from domestic and municipals dischargers, where Cabinet made Resolution Number (16) for the year 2013, "Bylaw on the House and Facilities' Connection System to the Public Sewage Network". The resolution for item (16) focus on the specification of industrial wastewater, where the COD limit is $2000 \mathrm{mg} / \mathrm{l}$ in order to allow to the industry to connect to the public sewage system [5].

These limits primarily aim at the reduction of organic and inorganic pollution loads, which promote eutrophication and impair public sewers [6], treatment facilities, environment, and public health. Consequently, municipal by-laws and effluent discharge standards dictate the level of wastewater treatment required and call for pretreatment of industrial effluents before connection to public sewer networks [5].

Based on the assumption and in reference to the literature reviews, the mentioned industrial facilities were considered as the main industrial pollutants, thus they were considered for pretreatment in this research. Advanced oxidation process (classical Fenton reaction) used in order to reduce the contamination specially the organic loads of the wastewater, so that to discharge it safely with acceptable specifications at the public sewer network. 


\section{Materials and Methods}

Samples of agro-food industrial wastewater have been collected from the dairy factory, and municipal slaughterhouse. The mixed of the previous samples have been tested to determine their physical and chemical properties. All samples prepared according to APHA (2005) [7]. The dairy samples contain sodium hydroxide $(\mathrm{NaOH})$ and phosphoric acid $\left(\mathrm{H}_{3} \mathrm{PO}_{4}\right)$ with concentrations (2.8-3\%) which come from flushing, rinsing and disinfecting of the process tanks and piping, in addition to the whey which is separated in the cheese making process, while the samples from slaughterhouse contained diluted blood, and wastewater produced from washing the slaughtered animals (manure, and undigested feed).

Table 1. General characteristics of the mixed agro-food wastewaters.

\begin{tabular}{|l|l|l|}
\hline Parameters & Value and results for the samples & Limits CR 16/13 \\
\hline $\mathrm{pH}$ & $6.96-7.23$ & $5-9.5$ \\
\hline COD (mg/l) & $15400-18200$ & 2000 \\
\hline Total solids (mg/l) & $2400-3705$ & - \\
\hline Total suspended solids (mg/l) & $188-220$ & 600 \\
\hline BOD $_{5}(\mathrm{mg} / \mathrm{l})$ & $7008-8198$ & - \\
\hline TKN (mg/l) & $411-570$ & - \\
\hline
\end{tabular}

The results shown above revealed high concentrations in the organic load in the mixed agrofood industrial wastewater from dairy (whey) and blood from the slaughterhouse in Nablus city.

\section{Experimental Procedure}

\subsection{Analytical Methods}

Physical parameters for mixed agro-food wastewater and treated wastewater were measured, pH measured by using (Metrohm-691). For TSS and TS parameters, those analyzed according to standard method.

For chemical parameters, which analyzed according to standard methods, Biological Oxygen Demand (BOD 5$) 5210$ B, Chemical Oxygen Demand (COD) - section 5220 D, Closed 
Reflux, Colorimetric Method-, Ammonia $\left(\mathrm{NH}_{4}-\mathrm{N}\right)$ Nesslerization method, total kjeldahl nitrogen.

\subsection{Experimental Procedure}

Classical Fenton's process has been applied with directly and with partially treatment.

Tests applied directly on the mixed of agro-food. Also applied partially for three samples:

1. Sample A: Coagulated by ferric chloride $\mathrm{FeCl}_{3} \cdot 6 \mathrm{H}_{2} \mathrm{O}$.

2. Sample B: Sedimentary sample without coagulant (untreated wastewater).

3. Sample C: Flocculation with Lime $\mathrm{Ca}(\mathrm{OH})_{2}$.

After partially treatment the supernatant, complete treatment by Fenton reagent by two methods, first one: without $\mathrm{pH}$ adjustment the second one: with $\mathrm{pH}$ adjustment, to get the accepted results.

\subsubsection{Directly Treatment By Fenton Reagent}

The classical Fenton's process was applied for mixed agro-food industrial wastewater samples directly; with initial COD between was 15400-18200 mg/1.

Fenton Reagent experiment:

1) $0.1 \mathrm{~L}$ of supernatant from all samples has been prepared to start reaction.

2) $\mathrm{pH}$ has been adjusted to acidic which equal 3 by adding acidic solution HCL.

3) Catalyst of Ferrous sulfate heptahydrate $\left(\mathrm{FeSO}_{4} \cdot 7 \mathrm{H}_{2} \mathrm{O} ; 5.2 \mathrm{mM} \mathrm{Fe}{ }^{2+}\right)$ added to the sample before adding hydrogen peroxide. The molar ratio of $\mathrm{H}_{2} \mathrm{O}_{2} / \mathrm{Fe}^{2+}$ w/w kept invariable at 10:1 and $\mathrm{H}_{2} \mathrm{O}_{2} / \mathrm{COD}(\mathrm{w} / \mathrm{w})$ kept constant at 2:1.

4) Three equal parts/or at once have been Added in 3 steps of $\mathrm{H}_{2} \mathrm{O}_{2}$ with wt. $30 \%(9.7$ M) (density $\left.1.11 \mathrm{~g} / \mathrm{cm}^{3}\right)$.

5) Terminate oxidation by the adjustment of samples' $\mathrm{pH}$ to 5-9 by adding lime $\mathrm{Ca}(\mathrm{OH})_{2}$. 
6) Sample kept for a period of 1 hrs to allow the settling of solids.

7) Supernatant has been gotten to analyze.

\subsubsection{Experimental Procedure of Partially Treatment samples}

1. Sample (A) coagulation with ferric chloride $\mathrm{FeCl}_{3} \cdot 6 \mathrm{H}_{2} \mathrm{O}$ : the sample of mixed raw dairy and slaughterhouse wastewater has been adjusted at room temperature $(20 \pm 1$ ${ }^{\circ} \mathrm{C}$ ). Then in the jar test $1.0 \mathrm{~L}$ volume of the sample coagulated by using ferric chloride $\left(\mathrm{FeCl}_{3} .6 \mathrm{H}_{2} \mathrm{O}\right)$ aqueous solution with dosage $1 \mathrm{~g} / \mathrm{L}$, the aqueous coagulant added in rapid mixing at $300 \mathrm{rpm}$ for $3 \mathrm{~min}$, then $30 \mathrm{~min}$ in slow mixing at $40 \mathrm{rpm}$. Followed by two hours of settling [8], [9].

2. Sample (B) sedimentation without coagulant: $1 \mathrm{~L}$ of the initial untreated wastewater

3. (at room temperature) at initial $\mathrm{pH}$ allowed settling for 2-4 h.

4. Sample $(\mathrm{C})$ flocculation with Lime $\mathrm{Ca}(\mathrm{OH})_{2}$ : One litter of initial wastewater has been mixed with raw lime $\mathrm{Ca}(\mathrm{OH}) 2$ by adding $1 \mathrm{~g} / 1$ of and mixing it rapidly for creating flocculation [8], [10], [11].

After partially treatment, that supernatant of samples had been gotten to complete treatment by Fenton's process as mentioned before once without $\mathrm{pH}$ adjustment and other with $\mathrm{pH}$ adjustment $=3$ and neutralization as following figures. 

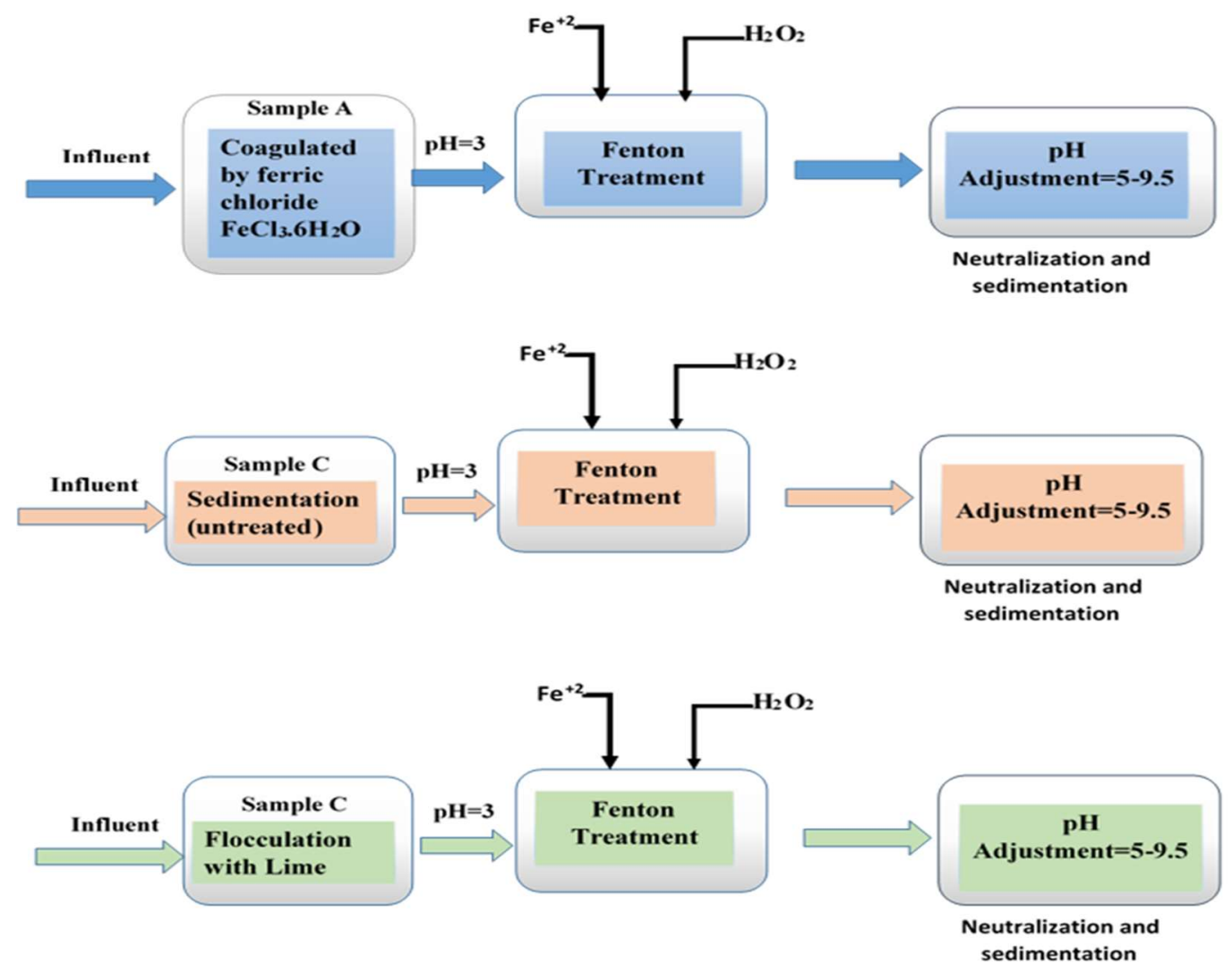

Figure 1. Steps of Fenton reaction experiment with $\mathrm{pH}$ adjustment for three recommended samples.

\section{Results and Discussion}

\subsection{Direct Treatment by Fenton Reagent}

Mixed of mixed-agro food wastewater has been treated directly by Fenton reagent, the results are not sufficient for CR 16/13 due to 45\% of COD removal in average, after treatment at $\mathrm{H}_{2} \mathrm{O}_{2} / \mathrm{COD}$ w/w ratio of $2: 1$ and $\mathrm{H}_{2} \mathrm{O}_{2} / \mathrm{Fe}^{+2} 10: 1$.

\subsection{Pre-Treatment Results}

\subsubsection{Before Creating Fenton Reaction for Three Samples}

The first pre-treatment sample (A) is coagulation with $\mathrm{FeCl}_{3} \cdot 6 \mathrm{H}_{2} \mathrm{O}$. The treatment has been carried out to remove suspended compounds of wastewater through the formation of a solid precipitate (sludge) which will be treated by Yoo et al., 2001[12]. The treatment carried out 
with dosage $1 \mathrm{~g} / \mathrm{L}$ of $\mathrm{FeCl}_{3} \cdot 6 \mathrm{H}_{2} \mathrm{O}$ of wastewater. The removal rates for $\mathrm{COD}$ are $(62 \%)$. This coagulant is also possible for TSS and TS removal $(74 \%, 28 \%)$ respectively.

The second pre-treatment (B) sample is sedimentation; it has been carried out to reduce the organic load, to improve mixed agro-food wastewater parameters [13], and to enhance the Fenton reaction. The result of pre-treatment in removal rates for COD (26\%), this result is feasible to improve wastewater parameters but it's not effective as coagulation with $\mathrm{FeCl}_{3} .6 \mathrm{H}_{2} \mathrm{O}$ and flocculation with lime $\mathrm{Ca}(\mathrm{OH})_{2}$ pre-treatments.

The third pre-treatment sample $(\mathrm{C})$ is flocculation with lime $\mathrm{Ca}(\mathrm{OH})_{2}$ [10], [11]. Results from this pretreatment showed more favorable values than the mentioned pretreatment and have been adopted in this research in the treatment of mixed agro-food wastewater before Fenton reaction. The result of pre-treatment in removal rates for COD (68\%), TSS (58\%), and in TS $(19 \%)$.

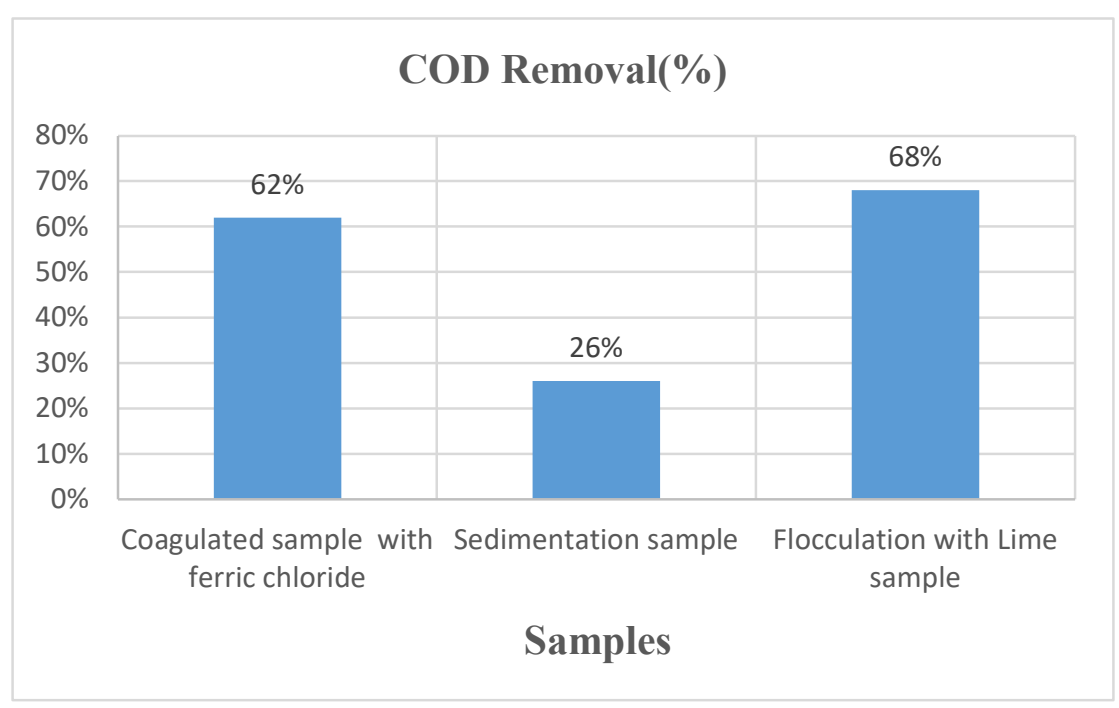

Figure 2. COD removal (\%) for samples after partially treatment.

According to results of COD removal, Sample A and $\mathrm{C}$ had been recommended for further tests. 


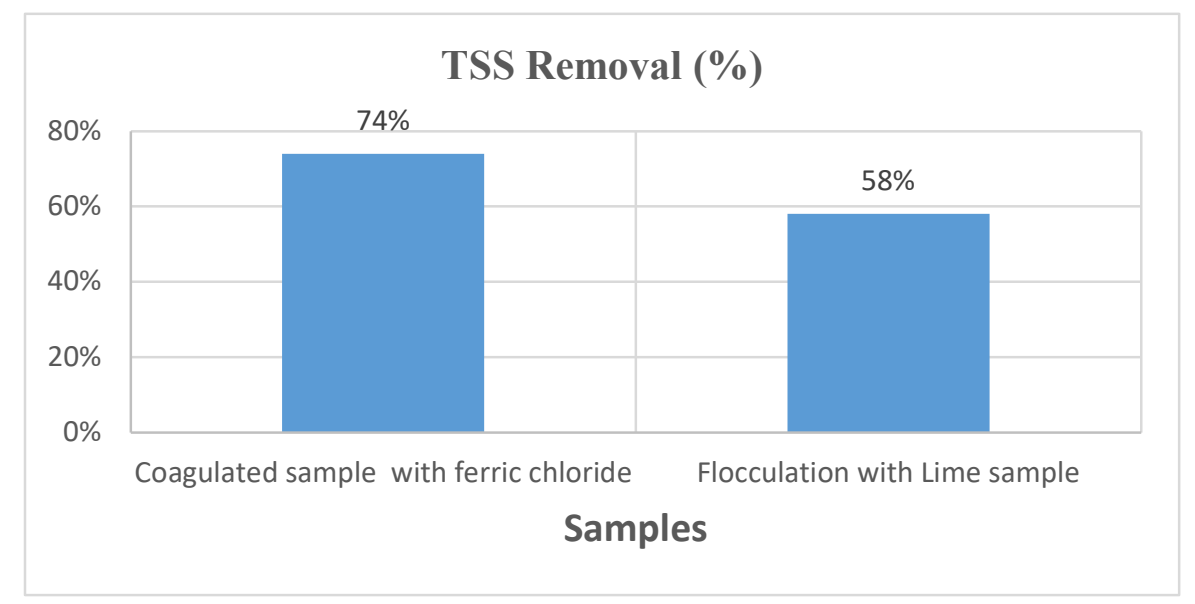

Figure 3: TSS removal (\%) for samples after partially treatment.

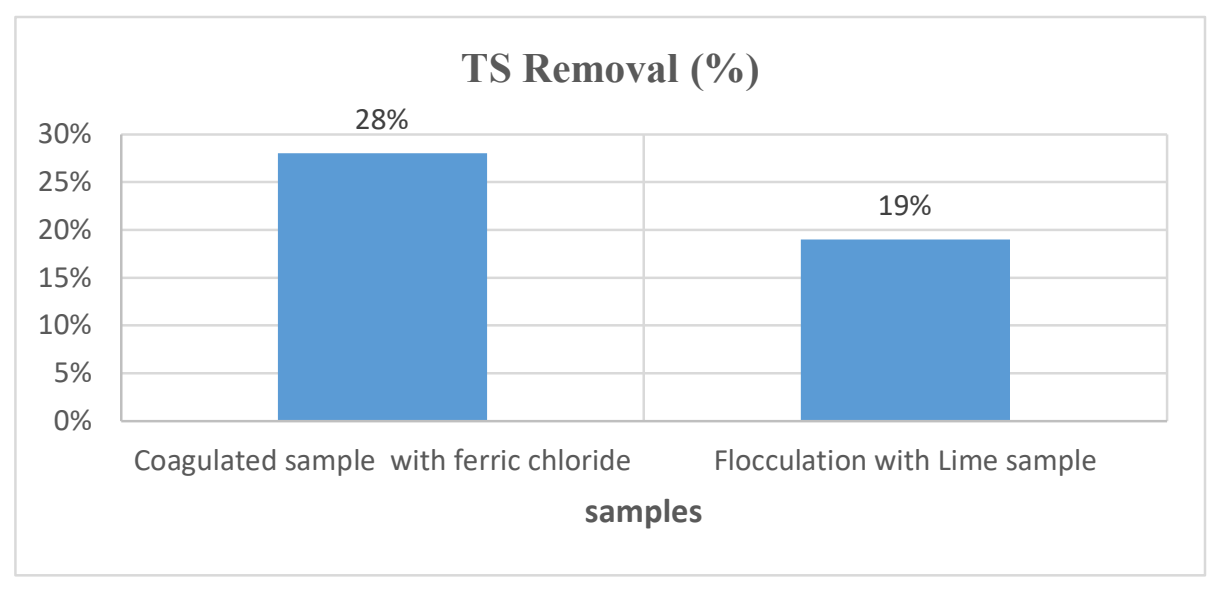

Figure 4. TS removal (\%) for samples after partially treatment.

\subsubsection{Results of Fenton Treatment after Partially Treatment}

\subsubsection{Treatment by Fenton Reagent without pH Adjustment}

At the first time, the $\mathrm{pH}$ left without adjustment to start Fenton reaction for samples:

1. Sample A: Coagulated by ferric chloride $\mathrm{FeCl}_{3} \cdot 6 \mathrm{H}_{2} \mathrm{O}$.

2. Sample B: Sedimentary sample without coagulant (untreated wastewater.

3. Sample C: Flocculation with Lime $\mathrm{Ca}(\mathrm{OH})_{2}$. 
It was found that the best result come from the sample of flocculation sample. It has been found that the $\mathrm{COD}$ removal reached $54 \%$ at $\mathrm{pH}$ value 11 with $\mathrm{H}_{2} \mathrm{O}_{2} / \mathrm{COD}$ w/w $2: 1$, and $\mathrm{H}_{2} \mathrm{O}_{2} / \mathrm{Fe}^{2+} 10: 1$.

while COD removal of coagulated by ferric chloride and sedimentation samples are equal $28 \%$ and $26 \%$ respectively at $\mathrm{H}_{2} \mathrm{O}_{2} / \mathrm{COD} w / \mathrm{w} 2: 1, \mathrm{H}_{2} \mathrm{O}_{2} / \mathrm{Fe}^{2+} 10: 1$, and $\mathrm{pH}$ values are equal 8 and 10.5 respectively. The performance of Fenton reaction in COD removal shown in the Figure 5 for three samples.

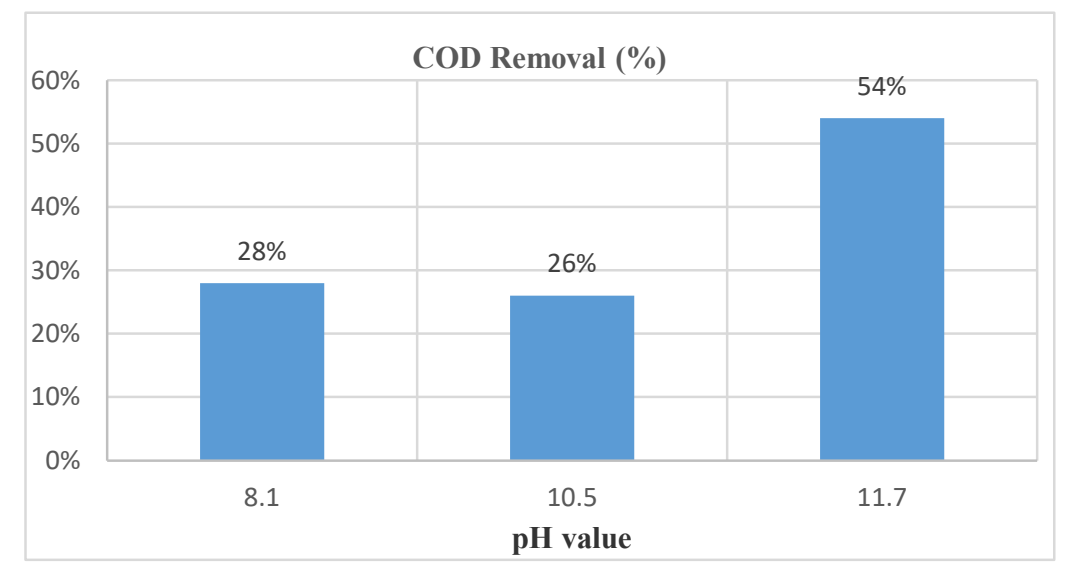

Figure 5. COD removal (\%) for three samples at initial $\mathrm{pH}$ without adjustment.

By leaving the samples without $\mathrm{pH}$ adjusting, the COD removal efficiency is not satisfactory in order to achieve CR 16/13.

\subsubsection{Treatment with $\mathrm{pH}$ Adjustment and Neutralization}

An acidic solution (HCL) has been used to modify the $\mathrm{pH}$ value from basic to acid media in order to make adequate conditions to start reaction. It is found that the degradation efficiency increased rapidly, organic removal was significantly higher in acidic conditions at $\mathrm{pH} 3$ than under alkaline conditions.

The optimum $\mathrm{pH}$ for the Fenton reaction is approximately 3 according to various literatures due to avoid precipitation of iron oxide-hydroxide which enhance the reaction [14]. It is the 
best case for the production of hydroxyl radicals, which is responsible for the breakdown of organic matter and responsible for oxidation reaction [13]. The ratio of $\mathrm{H}_{2} \mathrm{O}_{2} / \mathrm{COD} \mathrm{w} / \mathrm{w}$ kept $2: 1$ and $\mathrm{H}_{2} \mathrm{O}_{2} / \mathrm{Fe}^{2+} 10: 1$.

The results of the experiments showed that the best sample in removal of organic load is the flocculation with lime $\mathrm{Ca}(\mathrm{OH})_{2}$. It has been found that the removal rate for COD reached 70 $\%$ and for TSS and TS removal reached 65\%, 47\% respectively, and has been found that TKN reached $80 \%$ with the ratio of $\mathrm{H}_{2} \mathrm{O}_{2} / \mathrm{COD}$ w/w $2: 1$ and $\mathrm{H}_{2} \mathrm{O}_{2} / \mathrm{Fe}^{2+} 10: 1$, and at the room temperature and within 1 hour.

While COD removal of coagulated by ferric chloride sample is equal $52 \%$ and for TSS and TS removal reached 68\% 48\% (Figure 6 and 7). Moreover, it has been found that TKN reached $69 \%$ at the same ratios (Figure 8 and 9).

For the sedimentation sample, the removal rate for COD reached $33 \%$. The value of COD removal is low, and not accepted so this sample has been excluded for other results. After treatment, all samples have been neutralized at $\mathrm{pH}=7.3$. The performance of Fenton reaction in COD removal shown in Figure 6, for treating three samples. By adjusting the $\mathrm{pH}$, value for the three samples, the COD removal efficiency satisfactory for the sample which pretreating by lime $\mathrm{Ca}(\mathrm{OH})_{2}$, in order to achieve CR 16/13.

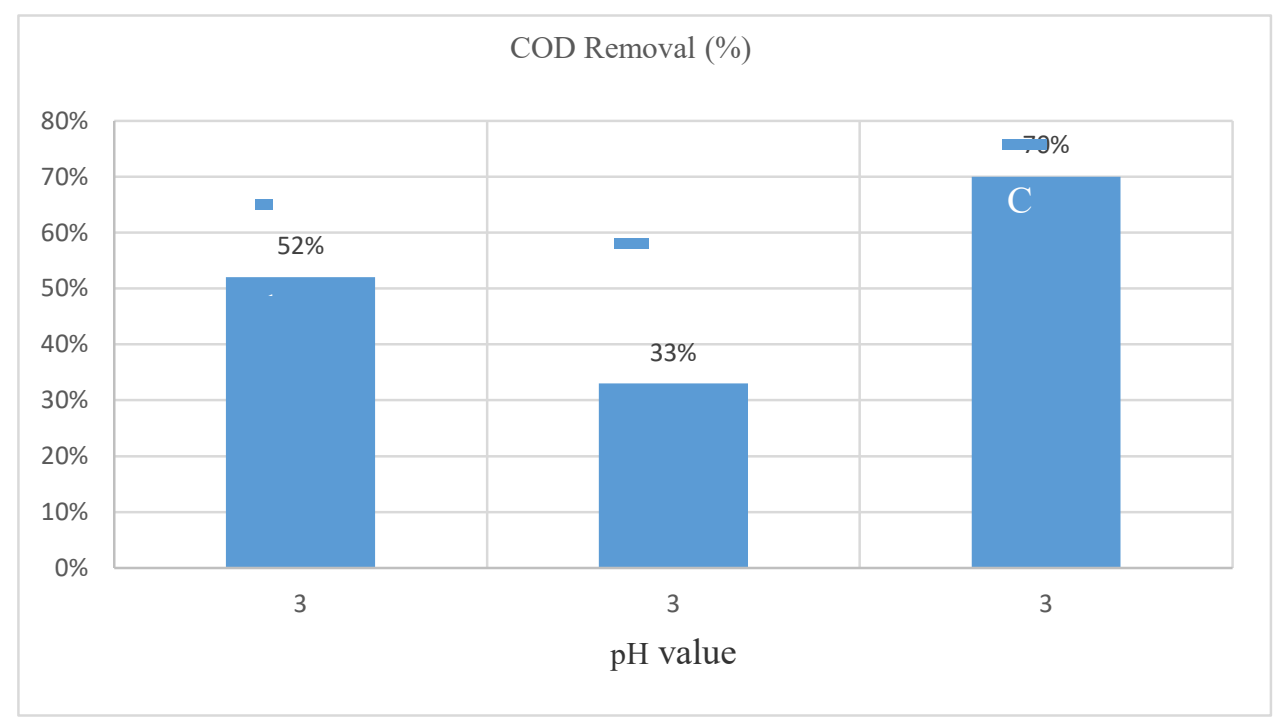

Figure 6. COD removal (\%) for three samples at $\mathrm{pH}=3$. 
According to results of COD removal, Sample A and C recommended for further tests.
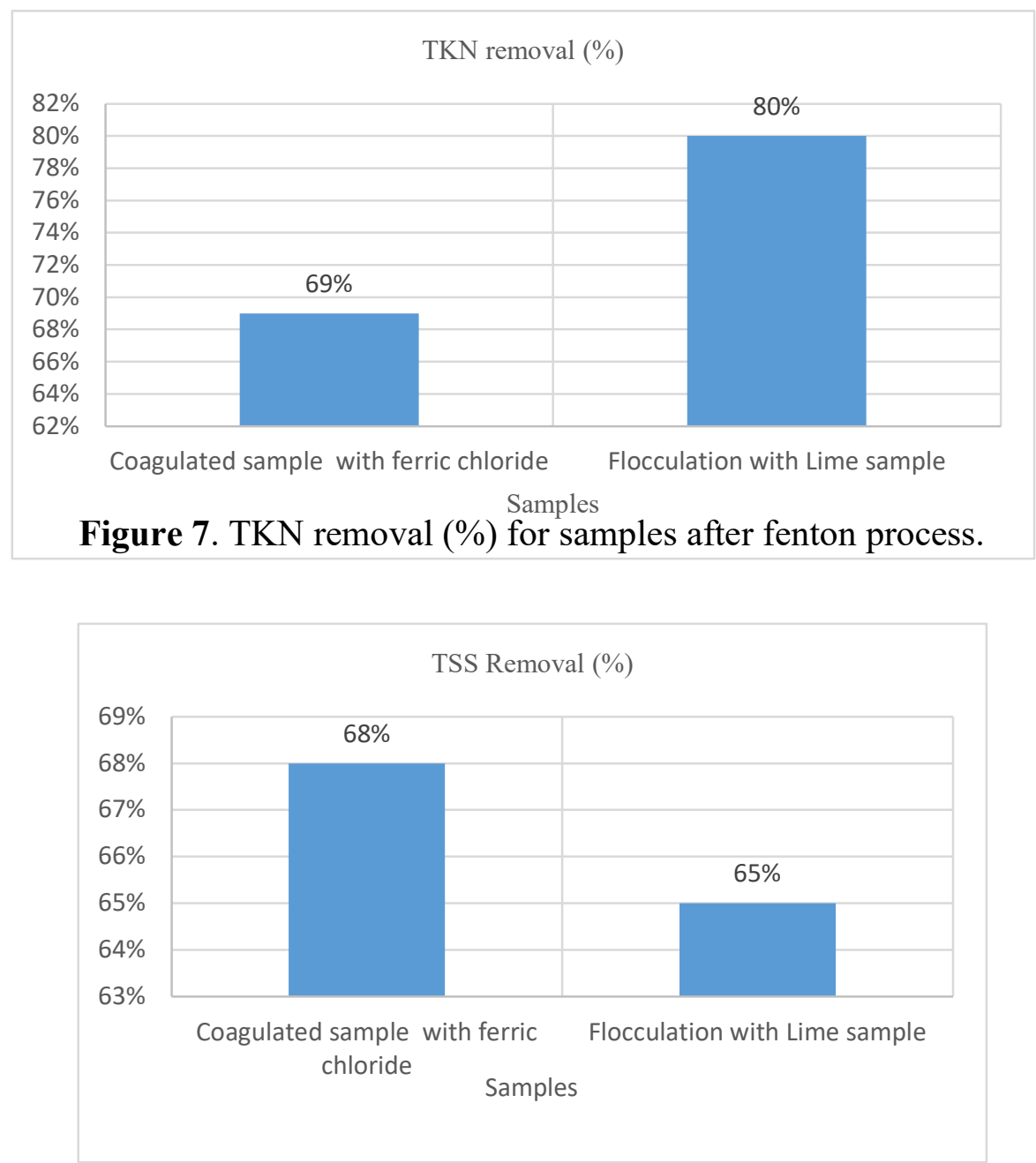

Figure 8. TSS removal (\%) for samples after Fenton process.

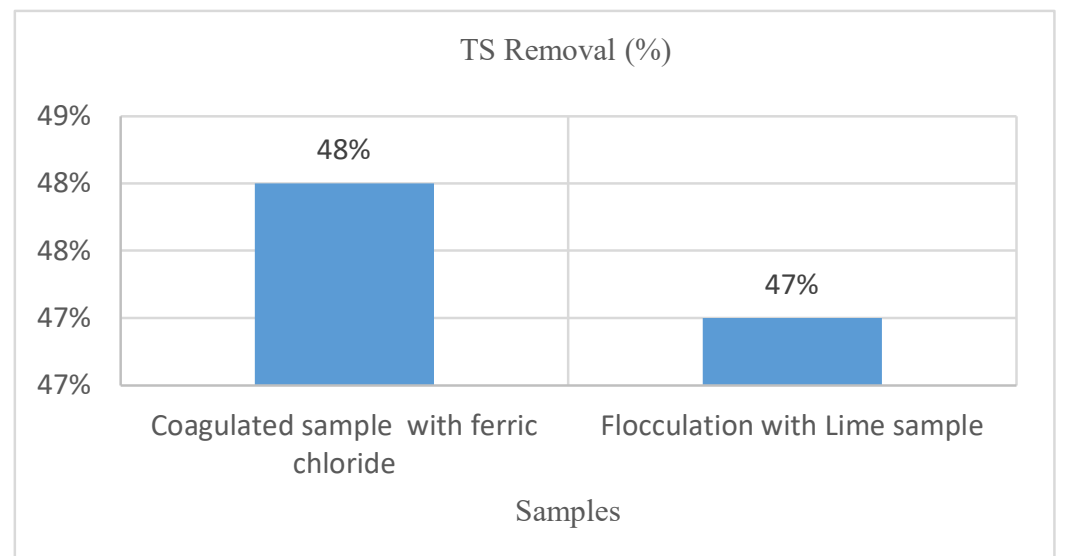

Figure 9. TS removal (\%) for samples after partially treatment. 


\subsection{Effect of $\mathrm{H}_{2} \mathrm{O}_{2}$ and Catalyst Dosage on Mixed Agro-Food Industrial Wastewaters Treatment Processes}

In Fenton reaction process $\mathrm{H}_{2} \mathrm{O}_{2}$ is the main source of hydroxyl radical $\bullet \mathrm{OH}$ which produced under catalyst, and has a key role in reducing the organic load of wastewater. The optimal dosage of hydrogen peroxide was determined experimentally and by calculations.

Insufficient dosage or little of hydrogen peroxide $\mathrm{H}_{2} \mathrm{O}_{2}$ led to decrease in COD removal of the organic load regarding to insufficiency hydroxyl radical $\bullet \mathrm{OH}$. In contrast an increasing in dosage of $\mathrm{H}_{2} \mathrm{O}_{2}$ specially in treating wastewater with high COD value to increase the efficacy of COD removal, the excessive dosage of $\mathrm{H}_{2} \mathrm{O}_{2}$ will affect the microorganisms which used in removing contaminant, also an excessive in the concentration of $\mathrm{H}_{2} \mathrm{O}_{2}$ will result in self-disintegration into $\mathrm{H}_{2} \mathrm{O}$ and $\mathrm{O}_{2}$ [16]. In a recent review, Peres et al., [17] listed other advanced technologies including membrane-based processes, RO, UF and advanced oxidation processes, which are increasingly applied for agri-industrial wastewater treatment.

Experements were repeated many times to determine the best optimal dose for $\mathrm{H}_{2} \mathrm{O}_{2}$ and obtained an optimal $\mathrm{H}_{2} \mathrm{O}_{2} / \mathrm{COD}$ ratio (w/w) of $2: 1$. For the dosage of $\mathrm{FeSO}_{4}$ the increasing in the quantity of the catalyst it will affect the treated wastewater economically in removing excess $\mathrm{Fe}^{+2}$, and if it is decrease the reaction will not get suffiant behavier to produce hydroxyl radical $\bullet \mathrm{OH}$. Dosage of $\mathrm{FeSO}_{4}$ calculated in term of $\mathrm{H}_{2} \mathrm{O}_{2}$ and COD concentration, $\mathrm{FeSO}_{4}$ dose tested and it has been found that optimal ratio of $\mathrm{H}_{2} \mathrm{O}_{2} / \mathrm{Fe}^{+2}$ equal 10:1.

Table 2 shows the summary of total removal rate for the contamination for three samples.

Table 2. Removal rates of pollutants.

\begin{tabular}{|l|l|l|l|l|l|}
\hline Sample & $\begin{array}{l}\text { COD } \\
\text { removal } \\
(\%)\end{array}$ & $\begin{array}{l}\text { BOD } \\
\text { removal } \\
(\%)\end{array}$ & $\begin{array}{l}\text { TKN } \\
\text { removal } \\
(\%)\end{array}$ & $\begin{array}{l}\text { TSS } \\
\text { removal } \\
(\%)\end{array}$ & $\begin{array}{l}\text { TS } \\
\text { removal } \\
(\%)\end{array}$ \\
\hline $\begin{array}{l}\text { Sample of Coagulated by } \\
\text { ferric chloride } \mathrm{FeCl}_{3} \cdot 6 \mathrm{H}_{2} \mathrm{O}\end{array}$ & $82 \%$ & $80 \%$ & $69 \%$ & $92 \%$ & $63 \%$ \\
\hline $\begin{array}{l}\text { Sample of sedimentary } \\
\text { (without coagulant) }\end{array}$ & $33 \%$ & $29 \%$ & - & $21 \%$ & $15 \%$ \\
\hline $\begin{array}{l}\text { Sample of Flocculation } \\
\text { with Lime } \mathrm{Ca}(\mathrm{OH})_{2}\end{array}$ & $88 \%$ & $86 \%$ & $80 \%$ & $91 \%$ & $62 \%$ \\
\hline
\end{tabular}




\section{Conclusion}

Based on the results analysis of this study, the following conclusions are elucidated:

- A pre-treatment stage before Fenton process is necessary to reduce pollution load as required.

- Lime addition enhances pre- and Fenton reaction enhanced COD removal rates.

- Application of AOP achieved results complying with Nablus CR 16/13.

- Scaling up Fenton process at pilot plant warrants further studies for organic rich agro-food industrial wastewater.

The coagulation/flocculation was effective for the pre-treatment of agro-industrial wastewater, mainly for lowering the COD and TSS to levels, where further post-treatment stages including AOPs and/other biological processes are applied.

\section{Acknowledgment}

The Dutch program PADUCO provided partial funding for this research study.

Conflicts of Interest: The authors declare no conflict of interest.

\section{References}

1. Environmental Quality Authority (EQA). Water Pollution and its Impact on Human Health. Technical Report, Environmental Quality Authority. Ramallah, Palestine, 2015.

2. Ng, W.J. Industrial Wastewater Treatment. London: Imperial College Press, 2006.

3. Kolhe, A.S.; Ingale, S.R.; Bhole, R.V. Effluent of dairy technology. Shodh Samiksha Aur Mulyankan (International Research Journal), 2009, 2(5), 459-461.

4. GTZ. Anaerobic Treatment of Slaughterhouse Waste and Wastewater. Study and Report. https://energypedia.info/wiki/Anaerobic_Treatment_of_Slaughterhouse_Waste _and_Wastewater. (Accessed on 28 October 2020).

5. Ministry of Local Government. Bylaw on the house and facilities "connection system to the public sewage". Ramallah, Palestine, 2013. 
6. Khan, M.N.; Mohammad, F. Eutrophication: challenges and solutions. In: A.A. Ansari, S.S. Gill (eds.). Eutrophication: Causes, Consequences and Control, 2014, 1-15.

7. APHA. Standard Methods for Examination of Water and Wastewater. $21^{\text {st }}$ Ed. American Public Health Association, Washington, D.C., USA, 2005.

8. Hossaini, H.; Fatehizadeh, A.; Yousefi, N.; Reshadat, S.; Gilan, N.R.; Ghasemi, S.; Ahmadian, M. Application of enhanced softening process in slaughterhouse. Indian $\mathbf{J}$. Chem. Technol., 2013, 20(3), 217-221.

9. Dennett, K.E.; Amirtharajah, A.; Moran, T.F.; Gould, J.P. Coagulation: its effect on organic matter. J. Am. Water Work. Assoc. 1996, 88(4), 129-142.

10. Leentvaar, J.; Rebhun, M. Effect of magnesium and calcium precipitation on coagulationflocculation with lime. Water Res. 1982, 16(5), 655-662.

11. Mo, W.T.; Chen, T.; Tang, Y.Y. Optimization of lime softening-flocculation treatment process of groundwater by orthogonal experiment. Chem. Bioeng. 2013, 6(27).

12. Yoo, H. C.; Cho, S.H.; Ko, S.O. (2001). Modification of coagulation and Fenton oxidation processes for cost-effective leachate treatment. J. Environ. Sci. Health, 2001, 36(1), 39-48.

13. Dulova, N.; Trapido, M. Application of Fenton's reaction for food-processing wastewater treatment. Journal of Advanced Oxidation Technologies, 2011, 14(1), 9-16.

14. Fenton H.J.H. Oxidation of tartaric acid in presence of iron. J. Chem. Soc., Trans. 1894, 65, 899-910.

15. Katsumata, H.; Kawabe, S.; Kaneco, S.; Suzuki, T.; Ohta, K. Degradation of bisphenol an in water by the photo-Fenton reaction. J. Photochem. Photobiol. A, 2004, 162(2-3), 297-305.

16. Andreozzi, R.; Caprio, V.; Insola, A.; Marotta, R. Advanced oxidation processes (AOP) for water purification and recovery. Catal. Today, 1999, 53(1), 51-59. 
17. Amor, C.; Marchão, L.; Lucas M.S.; Peres, J.A. Application of advanced oxidation processes for the treatment of recalcitrant agro-industrial wastewater: a review. Water 2019, 11, 205. https://doi.org/10.3390/w11020205. 